\title{
Political Accountability and the Rule of Law
}

\section{Walter van Gerven}

(C) ERA 2011

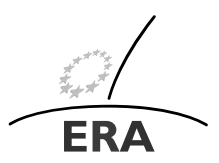

EUROPÄISCHE RECHTSAKADEMIE ACADEMY OF EUROPEAN LAW ACADEMIE DE DROIT EUROPEEN ACCADEMIA DI DIRITTO EUROPEO

\begin{abstract}
The author highlights the relevance of comparative law in the specific context of political accountability and the rule of law. He first presents different national features to deal with, or prevent, political scandals - free access to information, criminal prosecution, the use of ad-hoc tribunals, and a powerful constitutional court. He goes on to compare the notions of "rule of law" and "Rechtsstaat" in the English and German legal orders, which despite their synonymous use in Article 6 TEU are not quite identical. But comparing them in a European law context may help create a new autonomous concept at European level.
\end{abstract}

Keywords Rule of law $\cdot$ Rechtsstaat $\cdot$ Political accountability $\cdot$ Comparative law

\section{Introduction}

On 16 November 2006, Senior Law Lord Bingham delivered the sixth annual Sir David Williams lecture hosted by the Centre for Public Law at the University of Cambridge. The subject was the rule of law. ${ }^{1}$ A better subject could not be chosen by the person who is and was considered, in and outside the UK, as one of the greatest judges of his time. Unfortunately, on 11 September 2010 Lord Bingham passed away and left the legal world in and outside the UK alone after. As a friend of Lord Bingham, I thought not to be able to do better than choose the subject "Rule of law" to

\footnotetext{
${ }^{1}$ http://www.cpl.law.cam.ac.uk/past_activities/the_rt_hon_lord_bingham_the_rule_of_law.php. My contribution to the Liber Amicorum Tom Bingham and the Transformation of the Law was entitled "Scandals, Political Accountability and the Rule of Law. Counting Heads?", see van Gerven [17].
}

Professor Dr. W. van Gerven, Professor emer. ( $₫)$

K.U. Leuven, Tiensetraat 41, 3000 Leuven, Belgium

e-mail: Walter.VanGerven@law.kuleuven.be 
honour work and efforts of Judge John Toulmin at this occasion. At the last meeting in 2010 of the Board of Trustees, John retired, after 18 years of work and effort for ERA - of which 14 years as chairman of ERA's Board of Trustees - which work he had carried out in combination with his work as a High Court judge, at the Technology and Construction Court, London. Thus combining justiceship and trusteeship both part of the famous legal profession in the UK and the EU, as Judge and Trust there could be, I find, no better memory than the rule of law and justice to which he, John Toulmin has devoted his profession and life.

The Rule of law is not the only subject of this contribution. Difficult as it is to define the subject (infra) I combine it herein with other subjects which I have met in a context of political and ministerial accountability and responsibility. First I will discuss the notions of accountability and responsibility in a perspective of political scandals, relating to both the EU and Member States.

\section{Political Accountability for Scandals}

Scandals - particularly political scandals - have rightfully been labelled 'potential reputation' and 'trust depletors' in a field where 'vibrant democratic government' depends on 'social trust'. ${ }^{2}$ Political scandals not dealt with in the correct way will harm both democracy and the rule of law whilst a democracy's forceful reaction to highlevel political scandals will display its willingness to maintain trust in the political system. However, there are many ways to deal with political scandals depending on the tradition, the mentality and the legal system of a given country. As a general rule, at least in a parliamentary regime, political accountability towards parliament of high officials, cabinet members or civil servants for whom they are politically responsible, is in theory the strongest weapon as it forces the official to resign, and not infrequently to leave public life entirely. But it may be too strong in the case of a cabinet minister forced to resign not for misbehaviour or mismanagement of his own but on the part of civil servants. Moreover, the allegiance of a parliamentary majority to the ruling political party or parties may be such that parliament does not withdraw its confidence. Thus it has been observed, that in the Netherlands in the period 1945-1996, out of a total of forty-two ministers and secretaries of state who resigned, only ten resigned because a majority in parliament or one of the governing parties had made known its lack of confidence in the policy of the minister concerned. ${ }^{3}$ However, political accountability of high officials will not only be put in practice through political means - often by voluntary resignation, albeit frequently at the request of the head of government or of a political party - but also through other means as mentioned below.

\subsection{Free access to information: the Swedish precedent}

Open government and free access to public documents are no doubt crucial in avoiding wrongful behaviour by high officials. Within the European Union, Sweden is a

\footnotetext{
${ }^{2}$ Thompson [11], p. 252.

${ }^{3}$ Bovens [3], p. 88.
} 
champion of open government. The country got its first constitutional statute on the freedom of the press already in 1766, during the period of the Enlightenment, including a constitutional right for citizens to access and to copy official documents. ${ }^{4}$ Today the Freedom of the Press Act of 1949 and the Freedom of Expression Act of 1991 form part of the Swedish Constitution. The former protects freedom of expression and of information in the printed media, the latter protects most other mass media, e.g. radio and TV. ${ }^{5}$ As a rule the public authority concerned is not allowed to ask for the identity of the person who makes the request for access, or to ask for the purpose of the request. Moreover public officials, among others, are free to supply information about the contents of official documents (as opposed to supplying the actual documents) to the press, referred to as the freedom of the informant, which includes secret documents. Furthermore, a person involved in the production or publication of printed matter shall not disclose the identity of a person having provided information for publication. ${ }^{6}$ To be sure, no causal link can be proven to exist between open government and the prevention of scandals, but it will be difficult to deny that there is no such link at all.

\subsection{Criminal accountability: a French case}

Criminal prosecution is another means to combat political misbehaviour or mismanagement. This is the way that was chosen when France was confronted with a blood contamination scandal in the mid-eighties. Approximately 1200 hemophiliacs were infected with HIV following blood transfusions, of whom 250 died. Immense public commotion ensued and all legal avenues were used to placate the victims. Mr. Fabius, a former prime minister, and two other ministers were indicted, and a special court, the Cour de Justice de la République, was set up to try them in accordance with common criminal procedures. Several doctors were sentenced to prison by a criminal court in Paris. A special fund was created to indemnify victims for pecuniary and nonpecuniary damages. In 1999 the former prime minister and one of the two ministers were acquitted; the other, the Secretary of health, was found guilty, but not punished. The recourse, in this complex and delicate case, to criminal law was criticised by many for being an inadmissible change in emphasis from political to penal responsibility. It finally led to the unwritten rule which requires ministers to step down when they are at risk of becoming involved in criminal proceedings. ${ }^{7}$

\footnotetext{
${ }^{4}$ Bernitz [2], p. 916. The author mentions how this historically unique development came about as a result of the victory in 1765 of one of two fractions in Parliament, the Caps, over the other fraction, the Hats, which had been in power for a long time and were accused by the Caps of secrecy, corruption, misuse of power, and administrative mismanagement. The Caps therefore introduced the 1766 Freedom of the Press Act in order to stop censorship and open up freedom of the press and administrative transparency: ibid., in note 42 .

${ }^{5}$ Ibid., p. 916.

${ }^{6}$ On all this and many other matters, see further Österdahl [10], p. 339 ff. For recent developments, see Bull [4].

${ }^{7}$ See further van Gerven [15], pp. 72-73.
} 


\subsection{The role of ad hoc tribunals in the UK and Ireland}

Compared to the French approach of using criminal law as an instrument to combat political misbehaviour or mismanagement, the U.K. and Ireland play it 'softly' by using the device of 'ad hoc' tribunals of inquiry in view of exposing and judging the bad behaviour of cabinet ministers and other high officials. And indeed, at least viewed from the outside, it appears to be an effective way to interrogate not only cabinet ministers who might have a tendency to "pass the buck" but also civil servants. It is also a flexible (but expensive) instrument as it is for the chairman, usually a senior judge, to decide how to conduct the inquiry, which witnesses to hear and which documents to investigate, and how long the inquiry will take. A famous example in the U.K. was the inquiry in the nineties concerning the involvement of the Thatcher and Major governments in exports of arms and defence-related goods to Iraq and Iran which had taken place in the eighties. In the end, none of the three ministers involved was politically sanctioned: two of them were no longer in office when the report was released and the third one was not forced to resign because resignation was considered to be "constitutionally unnecessary and politically undesirable" by the Major government. However, the affair led in 1994 to the creation of a Committee on Standards in Public Life which was asked to stem the tide of corruption by recommending codes of conduct for ministers, civil servants and independent agencies. A more recent and less complex example was the Hutton inquiry into the suicide of Dr. Kelly, the British expert who had allegedly said to a journalist that the Blair administration was responsible for consciously misleading the public on the issue of weapons of mass destruction in Iraq. Not only did the prime minister's head of communication, Mr. Campbell, and other civil servants appear before the tribunal but Prime Minister Blair himself appeared as well. Mr. Campbell resigned in the aftermath and Mr. Blair took political responsibility, however without admitting personal fault. ${ }^{8}$

\subsection{Constitution and constitutional court: the case of Germany}

Germany is another example of a country which, like France, makes use of legal instruments, this time of constitutional law. In the Federal Republic ministerial accountability at the federal level is regulated in Article 64 of the Basic law which provides that ministers shall be appointed and dismissed by the Federal President at the proposal of the Federal Chancellor, who is himself elected by the Bundestag upon the proposal of the President and who must be dismissed by the President when a vote of no confidence in the chancellor is cast by a majority in the Bundestag (Articles 63(1) and 67(1)). In Germany political scandals have arisen, as in many other countries, in connection with illegal funding of political parties which came known after Chancellor Kohl's mandate expired. If the scandal had arisen earlier he would certainly have been made to resign and take the blame for his political party's wrongdoing, as happened in 1974 when Chancellor Willy Brandt took full responsibility for the espionage activities of his personal secretary, Günter Guillaume. Illegal funding is a matter which over the years has been the object of much case law from the

${ }^{8}$ Ibid., pp. 73-75. 
constitutional court, first deciding in 1958 that it is not unconstitutional for the state to make funds available, to allow political parties to finance their election campaign. However, in 1966 it changed position, holding that it is not for the state to contribute to the formation of the people's political will, but for the people to determine state politics. Later on, the court changed its position again, now recognising that many civil organisations are funded by the state and that private funding of political parties may have the same, or even a greater, adverse effect on the formation of the people's will as state funding - provided that state funding remains within appropriate limits. This is an illustration, out of many, of the politically important role that the constitutional court plays - and therefore the rule of law - both with respect to fundamental citizen rights in relation to the state, and to other citizens. ${ }^{9}$

\section{Rule of Law and Rechtsstaat}

The role which German constitutional law plays in such deeply intricate political matters shows how incrusted the principle of Rechtsstaat is in the German legal order.

\subsection{The rule of law in the English understanding}

Rule of law and Rechtsstaat are used in Article 6(1) EU Treaty as synonyms - not fully justified as we will see. In the English version the paragraph reads: "The Union is founded on the principles of liberty, democracy, respect for human rights and fundamental freedoms, and the rule of law, principles which are common to the Member States." As far as I know, in the UK the principle of rule of law has never been linked to the idea of state, but rather has been seen as one of the three overarching principles of British constitutionalism, apart from the doctrines of separation of powers and legislative supremacy, ${ }^{10}$ - the third meaning, in Dicey's words, was that Parliament has "the right to make or unmake any law whatsoever". Under the second meaning, the three types (legislative, executive and judicial) of political power should be separated from each other so that no one person or institution should exercise more than one type of power. ${ }^{11}$ Rule of law is the most difficult to define: in simple terms the doctrine requires that the subject is entitled to be ruled according to law, and that the law should be predictable. ${ }^{12}$ The rule was first propounded in 1885 by Dicey, and, as noted by Lord Bingham in his aforementioned lecture, had "attracted considerable controversy over the years which had elapsed since then". ${ }^{13}$ Nevertheless, reference was made to the doctrine in Sect. 1 of the Constitutional Reform Act 2005 which provides that "the Act does not adversely affect 'the existing constitutional principle

\footnotetext{
${ }^{9}$ Ibid., pp. 75-77.

${ }^{10}$ McLeod [9], p. 58.

${ }^{11}$ Ibid., pp. 64-65.

${ }^{12}$ Ibid., p. 66.

${ }^{13}$ Lord Bingham, supra fn. 1, pp. 1-2.
} 
of law' or 'the Lord Chancellor's existing constitutional role in relation to that principle.' " However, this inclusion in the Reform Act does not prevent, thus Lord Bingham, that "the meaning of this existing constitutional principle may no doubt have been thought to be too clear and well-understood to call for statutory definition, and it is true that the rule of law has been routinely invoked by judges in their judgments. But they have not explained what they meant by the expression, and well-respected authors have thrown doubt on its meaning and value."

Whence Lord Bingham's tentative in his lecture to define the concept and break it down in eight sub-rules. First the definition: "The core of the existing principle is that all persons and authorities within the state, whether public or private, should be bound by and entitled to the benefit of laws publicly and prospectively promulgated and publicly administered in the courts." ${ }^{4}$ Then the eight sub-rules: (i) the law must be accessible and so far as possible intelligible, clear and predictable; (ii) questions of legal right and liability should ordinarily be resolved by application of the law and not the exercise of discretion; (iii) the laws of the land should apply equally to all, save to the extent that objective differences justify differentiation; (iv) the law must afford adequate protection of fundamental human rights; (v) means must be provided for resolving, without prohibitive cost or inordinate delay, bona fide civil disputes which the parties themselves are unable to resolve; (vi) ministers and public officers at all levels must exercise the powers conferred on them reasonably, in good faith, for the purpose for which the powers were conferred and without exceeding the limits of such powers; (vii) adjudicative procedures provided by the state should be fair; (viii) the rule of law requires compliance by the state with its obligations in international law, the law whether deriving from treaty or international custom and practice governs the conduct of nations.

\subsection{The Rechtsstaat concept}

The German concept of Rechtsstaat finds its origin in the Vernunftstheorie (theory of rationality) which vests the legitimacy of the state in natural law, and in the enlightened "absolutism" of the late-eighteenth-century Prussian state of King Frederick the Great (1712-1786). Under these theories of rational man and freedom, it is for the state, seen as a liberal state submitted to individual rights and freedoms of its citizens, to support those citizens in the pursuit of personal liberty and self-development. This focus on human dignity and a liberal state at the service of its citizens explains the emphasis laid, with the enactment on 23 May 1949 of the Basic Law, on the dignity of men, and the duty for all public authority 'to respect and protect it', in its very first article. The Basic Law then goes on with a list of basic rights which "shall bind the legislature, the executive and the judiciary as directly enforceable law" (Article 1(3)), and establishes a framework for a federal state that, according to Article 20(1), shall be "democratic and social" - thus linking the principle of Rechtsstaat to the principle of Sozialstaat. It further states that "the legislature shall be bound by the constitutional order, the executive and the judiciary by law and justice" (Article 20(3)). The basic law recognises some principles as being of a higher order than the basic law

${ }^{14}$ Supra fn. 1, first full paragraph preceding fn. 13 of the lecture. 
itself by prohibiting in Article 79(3) the amendment of Articles 1 and 20 as well as the federal structure of the state. To underline how untouchable these provisions are, Article 20(4) grants all citizens "the right to resist anybody attempting to do away with this constitutional order, should no other remedy be possible." 15

\subsection{Convergence and conceptual contrast}

In addition to all of this, the principle of Rechtsstaat also encompasses a large number of principles relating to diverse subjects such as separation of powers, submission of all public authority to law, the requirement of a legal basis for all administrative action, judicial protection, state liability, legal certainty, basic principles of criminal law and procedure, and the principle of proportionality. ${ }^{16}$ Interestingly enough, these principles bear more resemblance with the sub-rules formulated by Lord Bingham than the articles of the German constitution itself: for indeed, like these sub-rules, they come closer to the British concept of the rule of law seen as a "principle of institutional morality" that guides "all forms of law-making and law-enforcement. In particular it suggests that legal certainty and procedural protections ... are fundamental requirements of good governance." 17 By contrast, the provisions of the German Basic Law itself purport to organise the state structure, in itself and in its relationship with the citizens and, moreover, focus directly on human dignity, human rights and social welfare - but that does not belong to the substantive content of the British rule of law; as Lord Bingham points out: not even adequate protection of fundamental human rights would "be universally accepted as embraced within the rule of law."18

\section{Comparative Law: Finding the Rule of Law, Not Counting Heads}

\subsection{Bringing in comparative law}

Turning to EU law, I start with a famous excerpt from Lord Bingham's judgment in Fairchild: ${ }^{19}$

\footnotetext{
${ }^{15}$ On the foregoing, see further van Gerven [15], pp. 107-109.

${ }^{16}$ For a full description, see Maurer [8], pp. 215-238.

${ }^{17}$ Jowell [6], p. 57.

${ }^{18}$ Lord Bingham, supra n. 1, text accompanying fn. 32 ff., who himself does not accept that proposition a proposition which makes professor Raz even say that "a non-democratic legal system, based on the denial of human rights, on extensive poverty, on racial segregation, sexual inequalities, and racial persecution may, in principle, conform to the requirements of the rule of law better than any of the legal systems of the more enlightened Western democracies" (as quoted by Lord Bingham). Which recalls me a passage written by the president of Israël's Supreme Court, Aharon Barak: "A friend once told me that during World War II, several Jews were in prison in Germany as a result of sentences received before the war broke out. The Gestapo did not harm those Jews because the law mandated that they not be exterminated in the death camps before finishing their prison sentences, and this rule of law had to be maintained. But when the prisoners finished serving their sentences, the Gestapo was waiting for them at the gate. The prisoners were taken to the death camps and murdered. The formal rule of law was observed." See Barak [1], p. 54.

${ }^{19}$ The HL judgment of 20 June 2002 in Fairchild $v$ Glenhave concerns three joined cases. The point of law referred to in the excerpt relates to the issue of double or multiple causation in an asbestos case.
} 
"Development in the law in this country cannot of course depend on a headcount of decisions and codes adopted in other countries around the world, often against a background of different rules and traditions. The law must be developed coherently, in accordance with principle, so as to serve, evenhandedly, the ends of justice. If, however, a decision is given in this country which offends one's basic sense of justice, and if consideration of international sources suggests that a different and more acceptable decision would be given in most other jurisdictions, whatever their legal tradition, this must prompt anxious review of the decision in question."

The excerpt is not about EU law but about English law and concerns the use of comparative law in considering a change in English law on a point deemed to be regulated in a more satisfactory and coherent way in other legal systems.

\subsection{Developing EU law through comparative law}

As we have seen above, comparative law has persuasive force, in some jurisdictions more than in other. Arguments of comparative law may persuade judges, as in Fairchild, to bring about a change in their own law when they are convinced that a solution applied in another system would lead to better, more acceptable results. In the context of European Union law, comparative law arguments drawn from Member State laws have not only persuasive force but also creative force in that rules which Member States have in common, will in certain instances explicitly, and sometimes impliedly, be considered to be part of EC/EU law. The most explicit example is found in Article 288(2) EC Treaty which reads: "In the case of non-contractual liability, the Community shall, in accordance with the general principles common to the laws of the Member States, make good any damage caused by its institutions or by its servants in the performance of their duties." It is thus for the ECJ in last instance, to give substantive content to tort liability rules for breaches of Community law by Community institutions or organs, and by analogy (as proclaimed in the ECJ's Francovich judgment), by Member State institutions and organs. ${ }^{20}$

\section{3 "Common principles" as a source of EU law}

Another example of judicial 'law finding' in EU law is Article 6 EU Treaty quoted above in connection with rule of law and Rechtsstaat, where these and other principles are called to be "principles which are common to the Member States". It is up to the Member State and European judiciaries, in the last instance the ECJ, to give substance to these common principles when their content is disputed - a task which will not be easy, given the fact that these principles will not be as common as may be assumed, and like our discussion of the principles of the rule of law and Rechtsstaat will have displayed. To be sure, 'common' does not mean 'identical', certainly not now in a Union of 27 Member States. And indeed, within the European Union, principles and solutions that are "common to the legal systems of the Member States", are not

\footnotetext{
${ }^{20}$ See my contribution, van Gerven [14]; also in the same book Tridimas [12].
} 
ready-made but come about as a result of a long process of cross-fertilisation within and among EU and Member State institutions, legislative, judicial, administrative and educational, and in a context of understanding, cooperation and convergence. ${ }^{21}$

\section{EU Commissioners: Ministers in the Making?}

\subsection{Political accountability before the European Parliament}

As in the Member States, also in the EU, political scandals have helped to shape political accountability, in this case on behalf of members of the European Commission to be compared with cabinet ministers at the national level. According to Article 201 EC Treaty the European Parliament can vote a motion of censure with special quorum and voting majorities against the Commission who then "shall resign as a body." After all these years the procedure has not yet been applied in full but came very close to that, back in 1999, when allegations of mismanagement and nepotism were raised against some members of the Commission, particularly Mrs. Cresson, then under the presidency of Mr. Santer. The motion of censure would have been voted if the two major political parliaments had not disagreed as to whether the whole Commission should resign or rather only Mrs. Cresson should be forced to resign.

\subsection{Investigation by ad hoc committees}

In the absence of a qualified majority the European Parliament finally decided to install a committee of five, called independent experts three in auditing and two in law. The committee examined the allegations and interviewed several of the Commissioners, apart from the president, mainly those allegedly involved. When the report was submitted to the Parliament in the afternoon of 15 March 1999, the Commission decided the same night to resign as a body of its own initiative (and stay on as a caretaker Commission until the appointment of a new Commission under Mr. Prodi). ${ }^{22}$ After the Commission's resignation the same committee was asked to analyse the Commission's "current practice and proposals for tackling mismanagement, irregularities and fraud." The second report, 286 pages long, and formulating more than 90 recommendations, was submitted on 10 September $1999 .{ }^{23}$ The last chapter, Chap. 7 , of the report dealt with the subject of integrity, responsibility and accountability in European political and administrative life.

\subsection{Committee proceedings on a comparative basis}

Needless to say that, in their two reports, the members of the committee drew to a large extent on the (auditing and legal) heritage of the Member States. That was particularly true for the introduction of the first report for which the committee members

\footnotetext{
${ }^{21}$ See further my contribution, van Gerven [14], pp. 138-144. See also my contribution, van Gerven [16], p. $406 \mathrm{ff}$.

${ }^{22}$ For a full account, see van Gerven [13].

${ }^{23}$ For a discussion of the role of the committee and an important part of its recommendations, see Craig [5], pp. 1-30.
} 
had to rely on their own knowledge and wisdom in order to describe and analyse the status and independence of the committee, the scope of its inquiries, the nature of reprehensible acts to be examined, the standards of proper behaviour to be applied, and the kind of responsibility to be used as a benchmark. Regarding these points much inspiration was found in the "Seven principles of public life" as set out in the first report on Standards in Public life of the UK (then Nolan) Committee. Actually, the creation of the committee may itself have been modelled after the British "ad hoc" tribunals of inquiry (cf. supra) - strangely enough, because the European Parliament could have found a more specific and more solid legal basis in Article 193 EC Treaty. That Article allows the European Parliament, "at the request of quarter of its Members, to set up a temporary Committee of Inquiry to investigate ... alleged contraventions or maladministration in the implementation of Community law ...". As a matter of fact, not only the conduct of EU institutions, even that of national authorities in implementing Community law may be the subject of such an inquiry by the European Parliament. ${ }^{24}$ In preparing the second report the committee of independent experts was bound to draw even more inspiration from the Member States' constitutional laws and traditions. That was particularly true for Chap. 7 when it came to lay down a code of conduct for Members of the Commission, their cabinets and their administration, to describe their political, individual and collective, responsibility for own conduct and for that of 'their' civil servants, and to address issues such as enforcement of ethical responsibility, whistle-blowing and outsourcing.

\subsection{Towards an autonomous EU concept of the rule of law}

As with the principle of political accountability, also with regard to the principle of rule of law or Rechtsstaat Member State laws have served as a model for the introduction or rather transplantation of the principle in EU law, at least with regard to the Union's former first pillar, the European Community. Although Article 6 EU Treaty refers to both concepts explicitly, in the English respectively German version of the treaty (cf. supra), no definition was supplied in the text, leaving it to the European and national institutions, legislators and courts, to give substantive and procedural content to the principle. This was done over the years, mainly in case law of the ECJ. Characteristic of this evolution has been the emphasis on two basic features: submission of all public authority, including the legislature proper, to judicial review through efficient remedies; and the obligation of public authorities to provide legal certainty and to act only when there is a legal basis for it in the EC/EU treaties. I have described these features at length on another occasion and have then added some other characteristics relating to good governance, more particularly, the duty of officials to behave with integrity and efficiency and in accordance with due process requirements, to respect human rights in the performance of all their tasks, and to pursue equality and social justice in the performance of their duties. ${ }^{25}$ This enumeration may show that 'commonality' at the European level does not preclude the European principle of rule of law from going further than the principle as it is applied in some Member States,

\footnotetext{
${ }^{24}$ Lenaerts/Van Nuffel [7], pp. 397-399.

${ }^{25}$ Van Gerven [15], p. 109. For discussion of these themes, see pp. 110-157 and pp. 158-212.
} 
particularly the UK where review of legislative action, respect for human rights and pursuit of social justice are not universally accepted to be components of the rule of law.

\section{References}

1. Barak, A.: The Judge in a Democracy. Princeton University Press, Princeton (2006)

2. Bernitz, U.: Sweden and the European Union: on Sweden's implementation and application of European Law. Common Mark. Law Rev. 38, 903-934 (2001)

3. Bovens, M.: The Quest for Responsibility: Accountability and Citizenship in Complex Organisations. Cambridge University Press, Cambridge (1998)

4. Bull, T.: Changing principles of freedom of speech in Sweden? Eur. Public Law 8, 333-347 (2002)

5. Craig, P.: EU Administrative Law. Oxford University Press, London (2006)

6. Jowell, J.: The rule of law today. In: Oliver, D., Jowell, O., Jowell, J. (eds.) The Changing Constitution, 3rd edn., pp. 57-78. Clarendon, Oxford (1994)

7. Lenaerts, K., Van Nuffel, P.: In: Bray, R. (ed.) Constitutional Law of the European Union, 2nd edn. Thomson, London (2005)

8. Maurer, H.: Staatsrecht I, 3rd edn. Verlag CHBeck, München (2003)

9. McLeod, I.: Legal Method, 3rd. edn. Macmillan Co., Basingstoke (1999)

10. Österdahl, I.: Openness and secrecy. Eur. Law Rev. 23, 336-356 (1998)

11. Thompson, J.B.: Political Scandal: Power and Visibility in the Media Age. Cambridge Polity Press, Cambridge (2000)

12. Tridimas, T.: Liability for breach of community law: growing up and mellowing down? In: Fairgrieve, D., Andeneas, M., Bell, J. (eds.) Tort Liability of Public Authorities in Comparative Perspective, pp. 149-181. British Institute of International and Comparative Law, London (2002)

13. van Gerven, W.: Managing the European Union: for better or for worse? In: Markesinis, B.S. (ed.) The Clifford Chance Millenium Lectures. The Coming Together of the Common Law and the Civil Law, pp. 91-104. Hart Publishing, Oxford (2000)

14. van Gerven, W.: The emergence of a common European law in the area of tort law: the EU contribution. In: Fairgrieve, D., Andenas, M., Bell, J. (eds.) Tort Liability of Public Authorities in Comparative Perspective, pp. 125-147. British Institute of International and Comparative Law, London (2002)

15. van Gerven, W.: The European Union. A Polity of State and Peoples. Stanford University Press/Hart Publishing, Stanford/Oxford (2005)

16. van Gerven, W.: About rules and principles, codification and legislation, harmonisation and convergence, and education in the area of Contract Law. In: Arnull, A., Eeckhout, P., Tridimas, T. (eds.) Continuity and Change in EU Law, Essays in Honour of Sir Francis Jacobs, pp. 400-414. Oxford University Press, London (2008)

17. van Gerven, W.: Scandals, political accountability and the rule of law. Counting heads? In: Liber Amicorum Tom Bingham and the Transformation of the Law, pp. 91-106. Oxford University Press, London (2009) 